\title{
The unconventional single stage hydrolysis of potato starch
}

\author{
Lucyna Słomińska ${ }^{1,}$, *, Roman Zielonka ${ }^{1}$, Leszek Jarosławski ${ }^{1}$ \\ ${ }^{1}$ Institute of Agricultural and Food Biotechnology, Department of Food Concentrates and Starch Products, \\ ul. Starołęcka 40, 61-361 Poznań, Poland, \\ ${ }^{2}$ University of Zielona Góra, Faculty of Biological Sciences, ul. Prof. Z. Szafrana 1, 65-516 Zielona Góra, Poland \\ "Corresponding author:ls@man.poznan.pl
}

Enzymatic depolymerisation of starch to glucose or maltose is carried out by starch- degrading amylases during a two-stage hydrolysis: liquefaction using bacterial $\alpha$-amylase followed by saccharification with glucogenic (fungal amylase) or maltogenic (fungal or bacterial) amylases. As a rule, these enzymes are applied separately, following the recommendations concerning their action provided by the enzyme manufacturers. The study presents our attempts to determine the reaction conditions for a simultaneous action of liquefying and saccharifying enzymes on pre-treated potato starch. Hydrolysis was run by Liquozyme Supra, Maltogenase 4000L and San Super 360L enzymes (Novozymes) at different temperatures. During the single-stage method of starch hydrolysate production the most desirable results was obtained for the maltose hydrolysate at $80^{\circ} \mathrm{C}(51.6 \mathrm{DE})$ and for the glucose hydrolysate at $60^{\circ} \mathrm{C}(96 \mathrm{DE})$. The analyses indicate that the application of a single-stage hydrolysis of starch to maltose or glucose makes it possible to obtain a degree of starch saccharification comparable with that obtained in the traditional two-stage hydrolysis.

Keywords: carbohydrate, dextrose equivalent, enzymes, hydrolysis.

\section{INTRODUCTION}

Starch hydrolysates (maltodextrins, syrups, crystalline dextrose) are obtained by controlled acid or enzymatic hydrolysis of starch. Two-stage hydrolysis of starch with subsequent liquefaction and saccharification is commonly used for the production of starch hydrolysates, i.e., maltose and glucose hydrolysates (maltose hydrolysate enzymatic hydrolysate with a dominant amount of maltose and glucose hydrolysate - enzymatic hydrolysate with a dominant amount of glucose $)^{1-6}$. The liquefaction stage converts insoluble starch granules into soluble polymer fragments (maltodextrins). In this process, thermostable bacterial alpha-amylase is used. The enzyme treatment is initially run at about $105^{\circ} \mathrm{C}$, followed by incubation at $90-95^{\circ} \mathrm{C}$. Liquefaction is usually a continuous process and takes about 1-3 hr. The next stage - the saccharification process - breaks polymer fragments into desired starch sugars. This is done by maltose-producing enzymes, such as microbial beta-amylase or fungal alpha-amylase, or by glucose-producing enzymes, i.e., glucoamylase. Saccharification of liquefied starch to glucose is usually run over extended time periods up to $72 \mathrm{hr}$. Shorter residence time for hydrolysis reaction, e.g., 30-48 hr, can be obtained by a simultaneous application of either glucoamylase and pullulanase or glucoamylase and isoamylase. The commonly used two-stage starch hydrolysis suffers from certain technological inconveniences, such as the necessity to change the temperature and $\mathrm{pH}$ in successive stages of hydrolysis, which results in an increased consumption of energy and auxiliary materials used in the purification of hydrolysates. The aforementioned inconveniences can be avoided by introducing a novel, unconventional single-stage method for starch hydrolysis, which would facilitate a simplification of the hydrolysis process, a more efficient utilization of enzymes, a shortened hydrolysis time and a higher efficiency of starch conversion ${ }^{7,8,9}$.

The aim of our current research was to compare the efficiency of the simultaneous action of liquefying and saccharifying enzymes (the single-stage method) with successive use of these enzymes (the two-stage method) in the process of starch hydrolysis.

The comparison of the methods was performed at temperatures ranging from 60 to $90^{\circ} \mathrm{C}$ recommended for the action of the enzymes applied. At the bottom limit of that temperature range no complete gelatinizing of all starch granules occurs ${ }^{10}$. Consequently, with the aim to reliably grasp the differences between the methods used, the process of gelatinizing was excluded through the use of cold-soluble potato starch as a substrate.

\section{MATERIALS AND METHODS}

\section{Materials}

Solamyl - cold water soluble potato starch (commercial product) was purchased from Chemet Co. (Poland). Solamyl was obtained by starch gelatinization and drying in a roll drum dryer. It is a dry product with a 5\% moisture content and the following granulation: below $0.2 \mu \mathrm{m}-18.3 \%, 0.2 \div 1.0 \mu \mathrm{m}-76.0 \%, 1.0 \div 1.6 \mu \mathrm{m}-5.6 \%$ and over $1.6 \mu \mathrm{m}-0.1 \%$. Due to the necessity to apply completely gelatinized and dissolved starch granules of native starch and to maintain comparable hydrolysis conditions at temperatures in the range of $60 \div 90^{\circ} \mathrm{C}$, the physically treated starch, i.e., the starch soluble in cold water, was selected as the substrate.

\section{Enzymes}

Alpha-amylase was produced by submerged fermentation of a genetically modified microorganism Bacillus licheniformis - Liquozyme ${ }^{\circledR}$ Supra with activity of $135 \mathrm{KNU} / \mathrm{g}(1 \mathrm{KNU}$ - the amount of enzyme which breaks down $5.26 \mathrm{~g}$ starch per hour using the_Novozymes standard method). Liquozyme ${ }^{\circledR}$ Supra is used in the initial liquefaction process of syrup production. The enzyme is applied at low $\mathrm{pH}(5.2 \div 5.6)$. The enzyme is thermostable at $90-95^{\circ} \mathrm{C}$ for $90-120$ minutes.

A heat-stable maltogenic alpha-amylase from Bacillus stearothermophilus is expressed in and produced by a ge- 
netically modified strain of Bacillus subtilis - Maltogenase $4000 \mathrm{~L}$ with activity of $4000 \mathrm{MANU} / \mathrm{ml}$ (1 MANU is defined as the amount of enzyme which hydrolyzes 1 micromole of maltotriose per minute in standard conditions). For industrial applications of Maltogenase $4000 \mathrm{~L}$, the recommended operation conditions are $60^{\circ} \mathrm{C}$ and $\mathrm{pH} 5.0 \div 5.5$.

A heat-stable saccharifying enzyme that contains both glucoamylase and acid-alpha-amylase, is produced by fermentation of a microorganism which is self-cloned according to the EU definition - San Super 360L with activity of $360 \mathrm{AGU} / \mathrm{ml}$ (1 AGU is the amount of enzyme which hydrolyzes one micromole of maltose per minute in specified conditions). The optimum general conditions of San Super are $55 \div 65^{\circ} \mathrm{C}$ and $\mathrm{pH} 4.5 \div 5.5$. All applied enzymes were purchased from Nozymes (Denmark).

\section{Starch hydrolysis assay}

Experiments were performed at $\mathrm{pH} 5.2$ for maltose hydrolysate and 5.0 for glucose hydrolysate (adjusted to this value with $0.1 \mathrm{M}$ hydrochloric acid) with $30 \%$ cold water soluble potato starch. During hydrolysis $\mathrm{pH}$ was controlled - the $\mathrm{pH}$ was slightly fluctuated $(+/-0,15)$. Starch hydrolysis was run with the use of a liquefying alpha-amylase Liquozyme ${ }^{\circledR}$ Supra and a saccharifying maltogenic enzyme - alpha-amylase Maltogenase 4000L or a saccharifying enzyme - glucoamylase San Super $360 \mathrm{~L}$. The enzymes were used in the following dosages: Liquozyme ${ }^{\circledR}$ Super at $0.66 \mathrm{KNU} / \mathrm{g}$ d.s. of starch, Maltogenase $4000 \mathrm{~L}$ at $24.8 \mathrm{MANU} / \mathrm{g}$ d.s. of starch and San Super $360 \mathrm{~L}$ at $2.84 \mathrm{EU} / \mathrm{g}$ d.s. of starch, respectively. The liquefying and saccharifying enzymes were used separately (two-step hydrolysis) or simultaneously (single-step hydrolysis).

Two-stage hydrolysis consisted in liquefaction of starch by the liquefying alpha-amylase for $2 \mathrm{hr}$ at $90^{\circ} \mathrm{C}$. After or without an inactivation of the liquefying enzyme, the maltogenic alpha-amylase or glucoamylase was added and the saccharification process was run for $46 \mathrm{hr}$ at $60^{\circ} \mathrm{C}$. The total hydrolysis time amounted to $2 \mathrm{hr}+$ $46 \mathrm{hr}=48 \mathrm{hr}$.

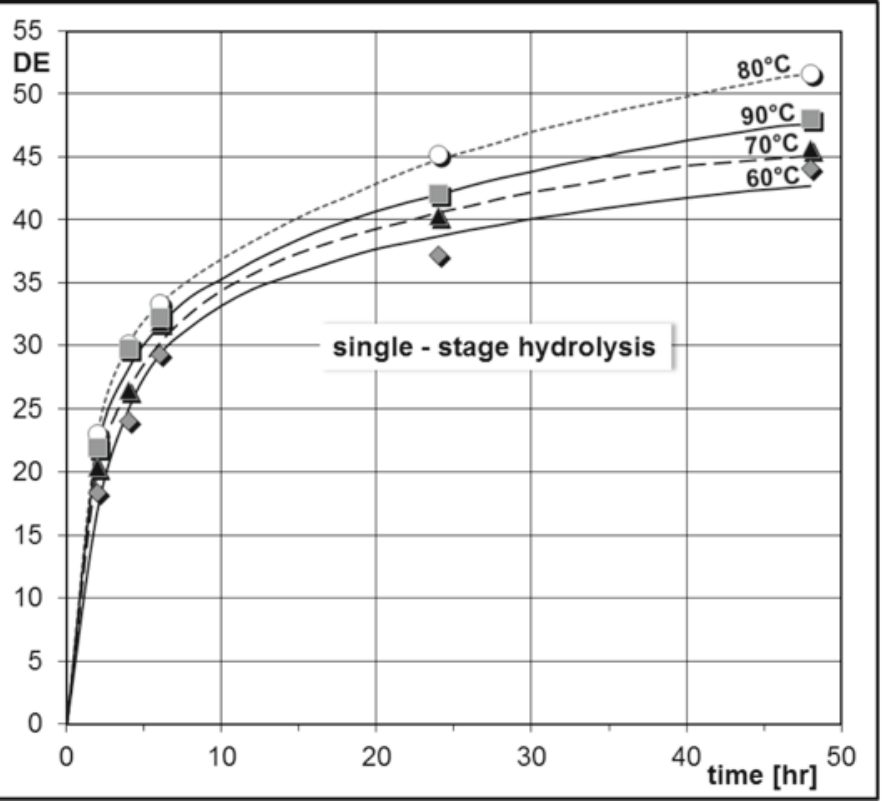

Single-stage hydrolysis of starch was performed by the simultaneous action of liquefying alpha-amylase and saccharifying maltogenic alpha-amylase or glucoamylase. Hydrolysis was carried out for $48 \mathrm{hr}$ at the following temperatures: $60,70,80$ and $90^{\circ} \mathrm{C}$.

\section{Analytical methods}

The following quantities were determined:

- the content of reducing sugars (DE) with the modified Schoorl-Rogenbogen method ${ }^{11}$.

- the residual starch - the amount of the residue after starch hydrolysis obtained by a double separation of the residue from the extract (by centrifugation) and a water elution of the residue by excess of water $\left(20^{\circ} \mathrm{C}\right)$ followed by separation of the residue on the filter and its complete drying ${ }^{12}$.

- the qualitative and quantitative carbohydrate composition by chromatography (HPLC) with the use of an Aminex HPX-42A column (4\% crosslinking of the cation exchange resin silver form) $-300 \times 7.8 \mathrm{~mm}$ (Biorad Laboratories), equipped with a refractive index detector. Samples of $20 \mu \mathrm{l}$ were filtered through a $0.45 \mu \mathrm{m}$ membrane (Millipore Laboratories) and eluted distilled and degassed water at $1.5 \mathrm{~cm}^{3} \mathrm{~min}^{-1}$ at $85^{\circ} \mathrm{C}$.

\section{RESULTS AND DISCUSSION}

\section{Effect of method on starch saccharification degree Maltose hydrolysates}

The results of the action of liquefying and saccharifying enzymes on potato starch during single-stage and two-stage hydrolysis are shown in Fig. 1.

During the single-stage starch hydrolysis within the temperature range of $60 \div 90^{\circ} \mathrm{C}$, the dextrose equivalent value (DE) increased. After a $48 \mathrm{hr}$ reaction run, the highest $\mathrm{DE}$ value was recorded at temperatures between $80 \div 90^{\circ} \mathrm{C}$; however, a slightly higher effect was obtained at $80^{\circ} \mathrm{C}$. During the two-stage hydrolysis, the inactivation or its lack in the liquefying enzyme did not result in an essential change in the DE value. When comparing the results of the single-stage hydrolysis at $80^{\circ} \mathrm{C}$ with those

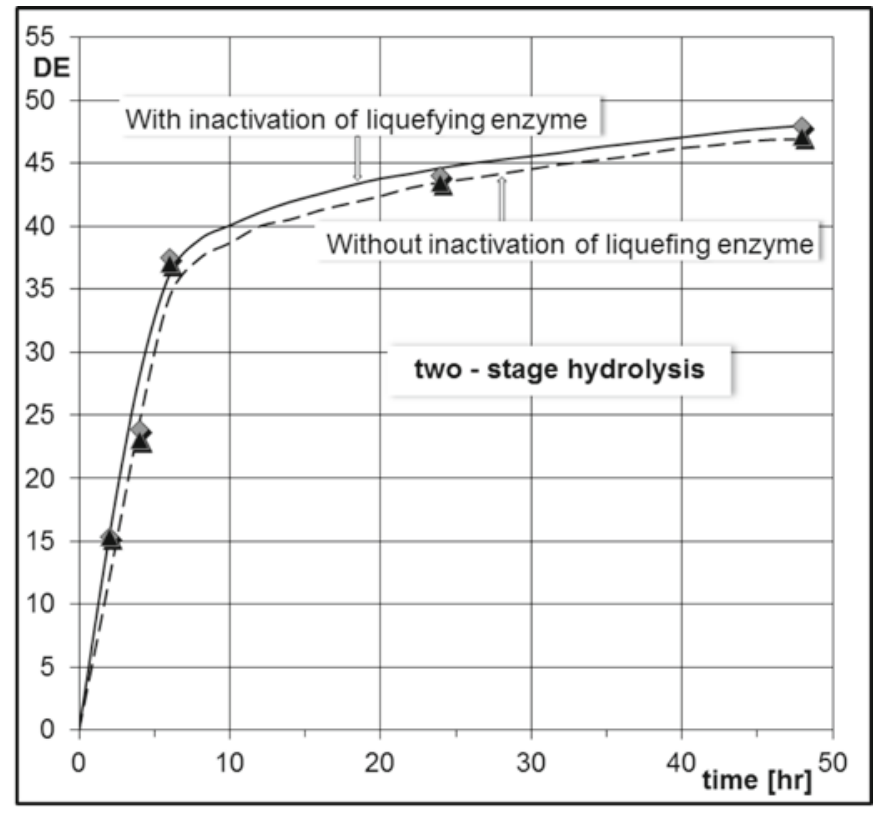

Figure 1. Flow diagram of the single- and two-stage methods for starch hydrolysis (maltose hydrolysate) 

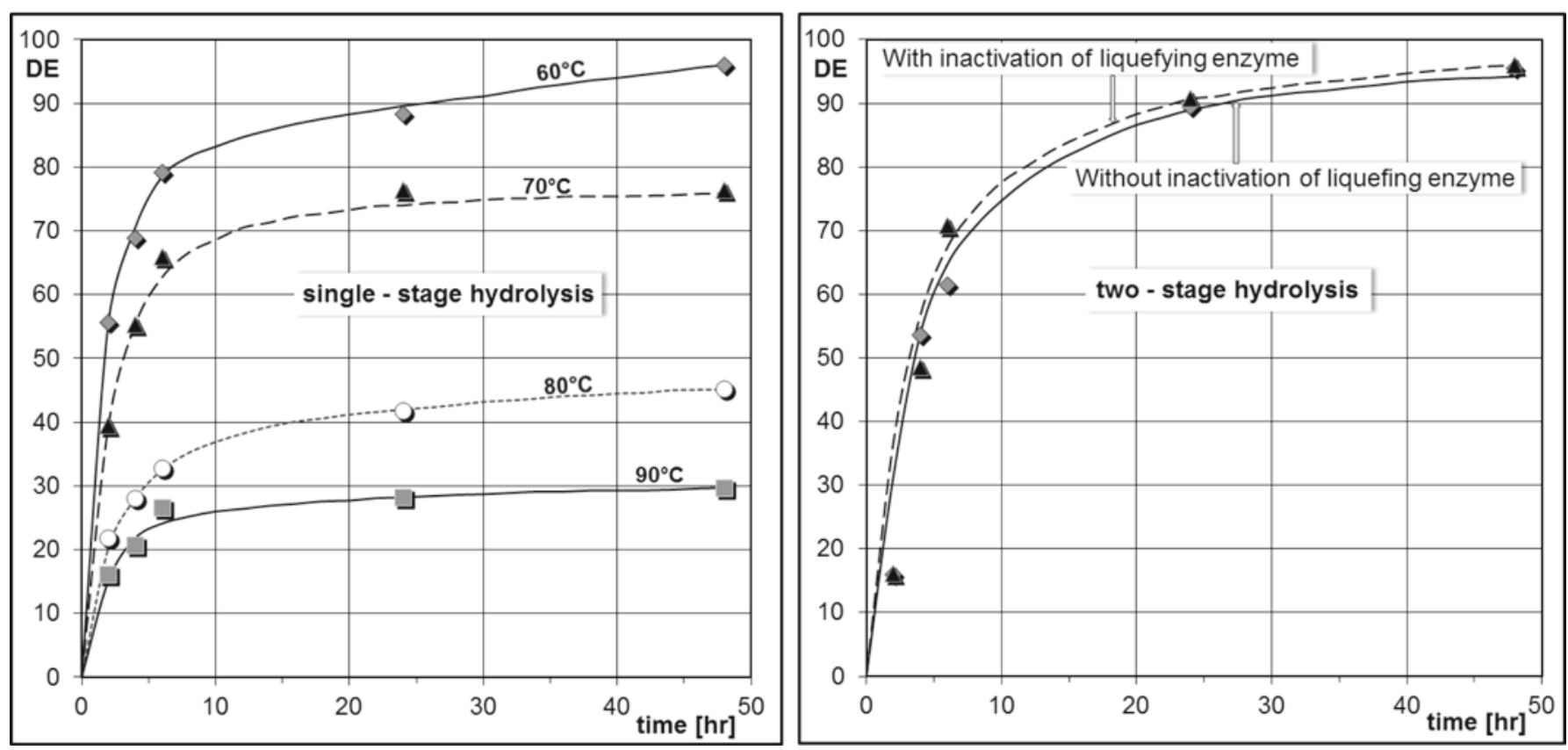

Figure 2. Flow diagram of the single- and two-stage methods for starch hydrolysis (glucose hydrolysate)

of two-stage hydrolysis without enzyme inactivation, it can be observed that the course of hydrolysis in both is similar (after $48 \mathrm{hr}$ ); however, the use of the single-stage method makes it possible to obtain a relatively higher final value of the dextrose equivalent - by $3.6 \mathrm{DE}$ $(51.6 \div 48.0 \mathrm{DE})$. As follows from Fig. 1, the hydrolysis at higher temperatures took place more intensively, in spite of the fact that the temperature of $60^{\circ} \mathrm{C}$, commonly used for the maltogenic enzyme, was exceeded.

Therefore, in order to obtain the highest dextrose equivalent in the production of maltose hydrolysates, it is advisable to continue research on the use of novel, considerably simplified single-stage hydrolysis of starch, consisting in the application of a constant temperature $\left(80^{\circ} \mathrm{C}\right)$ during the entire process of liquefaction and maltogenic saccharification.

\section{Glucose hydrolysates}

The results of an action of the liquefying and saccharifying enzymes on potato starch during the single- and two-stage hydrolysis to glucose are presented in Fig. 2.

The highest value of dextrose equivalent in the single-stage hydrolysis was recorded for the process run at $60^{\circ} \mathrm{C}(96.0 \mathrm{DE})$. The applied temperature resulted in a decrease in the final value of dextrose equivalent (after $48 \mathrm{hr}$ ); for $70^{\circ} \mathrm{C}$ it amounted approximately to $20.4 \%$, for $80^{\circ} \mathrm{C}$ approx. to $53 \%$, while for $90^{\circ} \mathrm{C}-$ approx. to $69 \%$, respectively.

In the case of the glucose hydrolysate, the fact that the temperature recommended by the enzyme manufacturer for the saccharifying enzyme was exceeded, led to a considerable decrease in the intensity of the hydrolysis process. Thus, it is not advisable to run saccharification at a temperature above $60^{\circ} \mathrm{C}$.

Despite the similar optimum temperature for saccharifying enzymes during the synergistic action of the bacterial alpha-amylase (Liquozyme ${ }^{\circledR}$ Supra), San Super $360 \mathrm{~L}$ is less stable than Maltogenase $4000 \mathrm{~L}$, because the fungal origin of the glucogenic enzyme (San Super $360 \mathrm{~L}$ ) is associated with a lower thermal stability than the bacterial maltogenic enzyme (Maltogenase 4000L).
Similarly as in the case of two-stage production of maltose hydrolysate, the production of glucose hydrolysate with and without the inactivation of the liquefying enzyme yields very similar results, i.e., 95.5 DE and 95.9 DE, respectively. A comparison of the results of the single-stage hydrolysis run at $60^{\circ} \mathrm{C}$ with those of the classical two-stage method shows that the course of hydrolysis is very similar. An analysis of the results shows that it is possible to obtain a high degree of saccharification (above $95 \mathrm{DE})$ also by the use of single-stage hydrolysis, i.e., the simultaneous action of the liquefying and saccharifying enzymes at a constant temperature of $60^{\circ} \mathrm{C}$.

Effect of applied hydrolysis method on contents of selected sugars

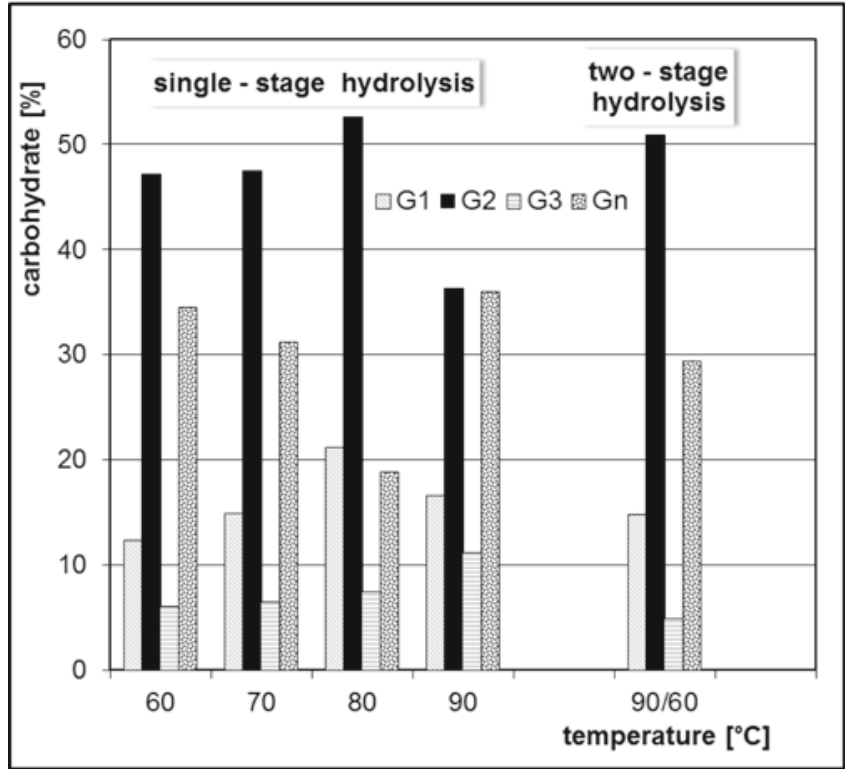

Figure 3. Contents of selected carbohydrates - glucose (G1), maltose $(\mathrm{G} 2)$, maltotriose $(\mathrm{G} 3)$ and higher sugars (Gn) - depending on the applied method of starch hydrolysis (maltose hydrolysate - after $48 \mathrm{hr}$ hydrolysis) 


\section{Maltose hydrolysates}

The contents of selected sugars obtained using singleand two-stage $48 \mathrm{~h}$ hydrolysis run at different temperatures $\left(60,70,80\right.$ and $\left.90^{\circ} \mathrm{C}\right)$ are compared in Figs. 3 and 4.

During the processing with the single-stage method, the temperature increase up to $80^{\circ} \mathrm{C}$ results in an increase in the content of glucose (G1) and maltose (G2); however, at $90^{\circ} \mathrm{C}$ their content diminishes distinctly, down to 16.6 and $36.3 \%$, respectively.

The increase in temperature (from 60 to $90^{\circ} \mathrm{C}$ ) resulted in an increase in the maltotriose (G3) content from 6.0 to $11.1 \%$, respectively. The amounts of higher sugars (G4-Gn) decreased with the temperature increase from 34.5 to $18.8 \%$. The application of $90^{\circ} \mathrm{C}$ resulted in an increased content of higher sugars $(36.0 \%)$, which is less advantageous in the production of maltose hydrolysates (the clarity of the product is lower). The observed decrease in the content of maltose and higher sugars
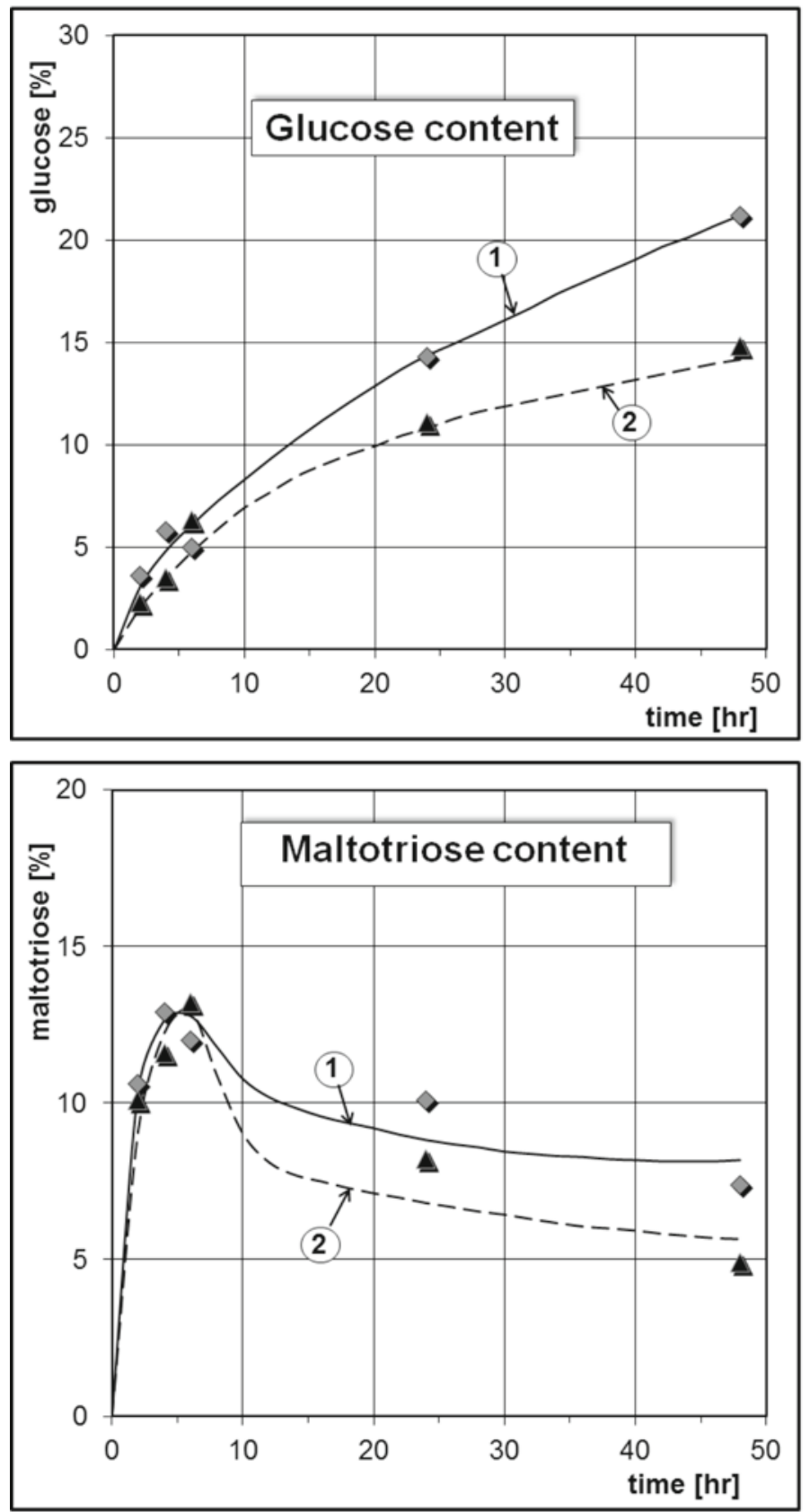

indicated a decrease in the activity of the liquefying enzyme at $90^{\circ} \mathrm{C}$. The results obtained indicate that it is justified to recommend the single-stage method within the temperature range of $60 \div 80^{\circ} \mathrm{C}$. The optimal temperature for the single-stage hydrolysis is $80^{\circ} \mathrm{C}$.

When comparing the methods of the production of maltose hydrolysate, i.e., the single-stage vs. two-stage method (for the recommended temperature of $80^{\circ} \mathrm{C}$ ) it can be found that slightly higher maltose and maltotriose contents were obtained in the former case. Namely, they amounted to 52.6 vs. $50.9 \%$ for maltose as well as 7.4 vs. $4.9 \%$ for maltotriose, respectively. In terms of the content of higher sugars, still better results (lower amounts) were recorded in the case of the use of the single-stage method (18.8 instead of $29.4 \%$ ). In turn, in the case of glucose content better results (lower amounts) were found during the processing with the two-stage method (14.8 vs. $21.2 \%)$. The quantitative differences
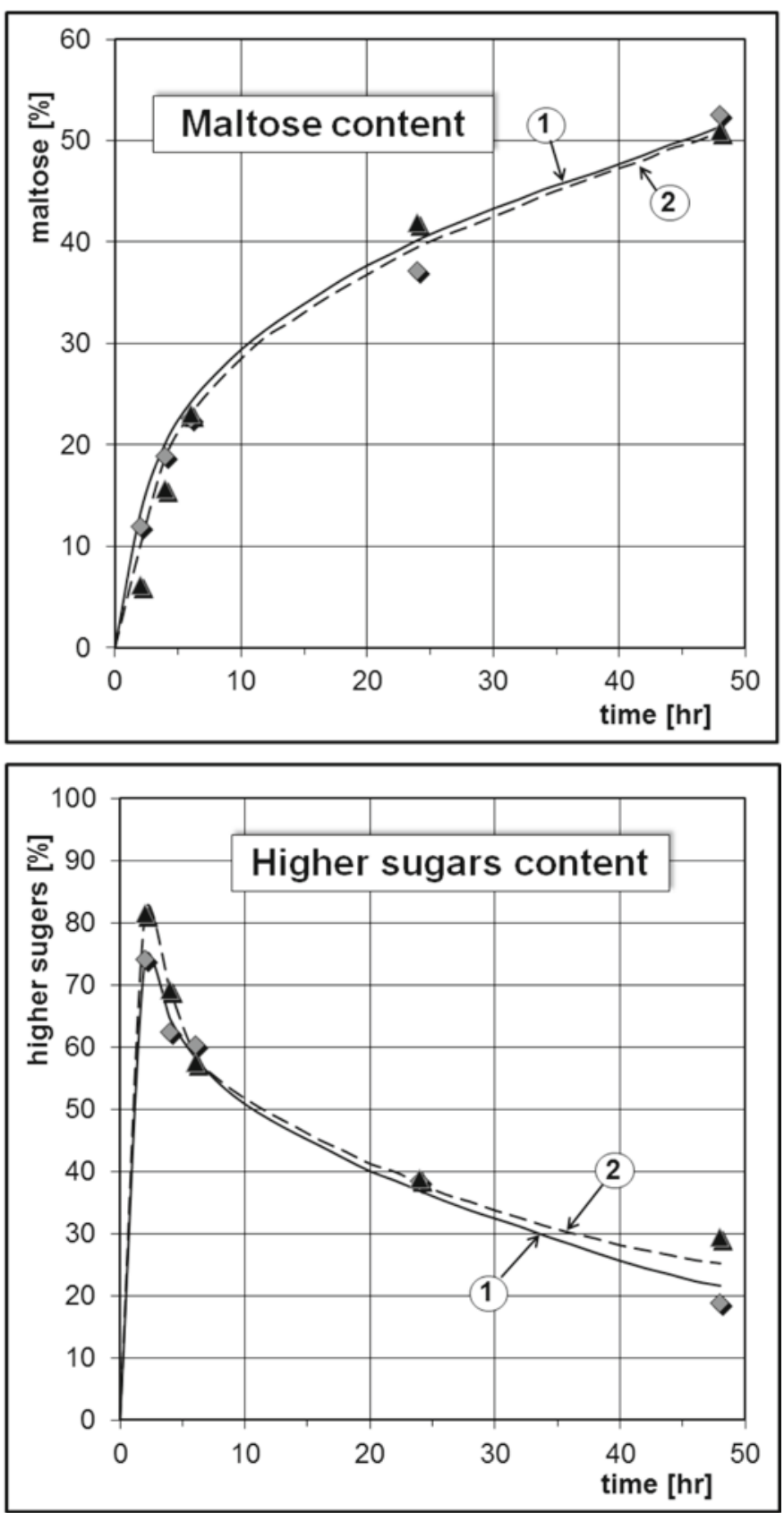

Figure 4. Changes in glucose, maltose, maltotriose and higher sugars content during starch hydrolysis (maltose hydrolysate - during 48 hr hydrolysis)

1. Single-stage method $\left(80^{\circ} \mathrm{C}\right)$

2. Two-stage method (without inactivation of liquefying enzyme) 
in the distribution of carbohydrates in both methods are associated with a different dynamics of the synergistic action of the used enzymes (alpha-amylase and maltogenic amylase) in the applied temperatures of hydrolysis $\left(60\right.$ and $\left.80^{\circ} \mathrm{C}\right)$ - the starch depolymerization products which are producing by the influence of alpha-amylase action are at the same time a convenient substrate for the maltogenic enzyme action.

Considering the application of maltose hydrolysate as a source of fermenting sugars $(\mathrm{G} 1+\mathrm{G} 2)$, a markedly better source of the maltose hydrolysate is that obtained by the single-stage starch hydrolysis $(21.2 \%+52.6 \%=$ $73.8 \%$ ) rather than the maltose hydrolysate produced by the two-stage method $(14.8 \%+50.9 \%=65.7 \%)$.

These observations can be very useful when choosing the method for starch hydrolysis (single-stage or twostage method) depending on the required carbohydrate composition of the produced starch hydrolysate. The single-stage method, in comparison with the two-stage method, makes it possible to increase the share of glucose and maltose by 43.2 and $3.3 \%$, respectively, and leads to a decreased higher sugar contents down to $36.0 \%$.

\section{Glucose hydrolysates}

The contents of selected sugars, obtained using the single- and two-stage $48 \mathrm{hr}$ method run at different temperatures $\left(60,70,80\right.$ and $\left.90^{\circ} \mathrm{C}\right)$ are presented in Figs. 5 and 6.

In the single-step method, due to an increase in temperature, a rapid drop of the glucose content was observed - from $98.2 \%$ at $60^{\circ} \mathrm{C}$ to $8.7 \%$ at $90^{\circ} \mathrm{C}$. Hence, the relative decrease in these amounts at $70^{\circ} \mathrm{C}, 80^{\circ} \mathrm{C}$ and $90^{\circ} \mathrm{C}$ was $14.0 \%, 89.1 \%$ and $89.5 \%$, respectively. The amount of maltose increased (during an increase in temperature from 60 to $80^{\circ} \mathrm{C}$ ) from 1.8 to $34.4 \%$, followed by a drop down to $17.8 \%$ at $90^{\circ} \mathrm{C}$. The amount

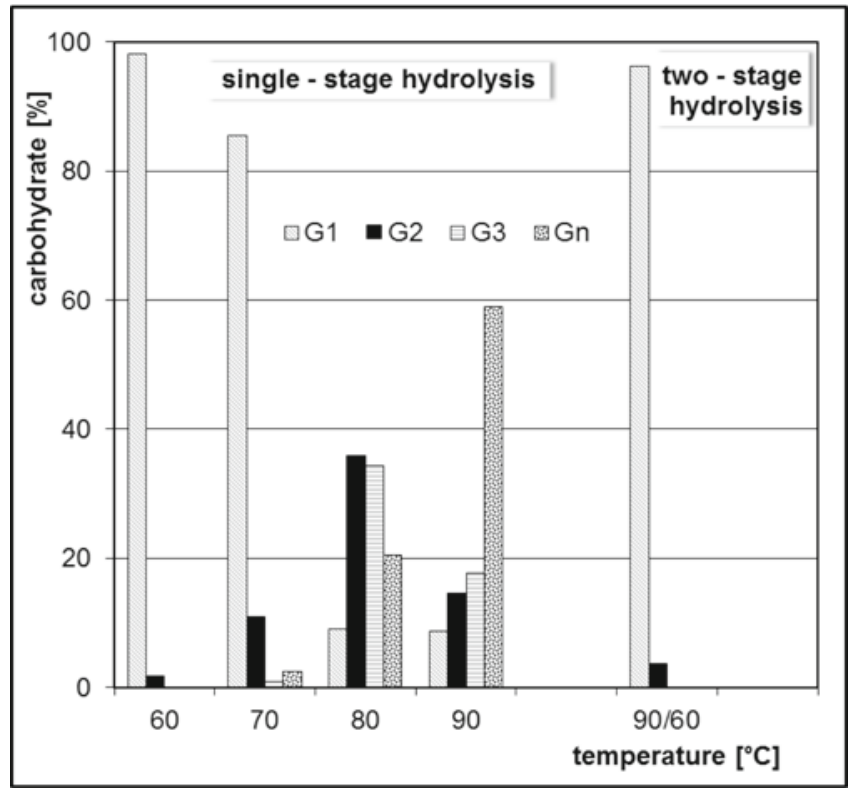

Figure 5. Contents of selected carbohydrates - glucose (G1), maltose (G2), maltotriose (G3) and higher sugars (Gn) - depending on the applied method of starch hydrolysis (glucose hydrolysate - after 48 hr hydrolysis)

1. Single-stage method $\left(80^{\circ} \mathrm{C}\right)$

2. Two-stage method (without inactivation of liquefying enzyme) of maltotriose reached its highest level $(34.4 \%)$ at $80^{\circ} \mathrm{C}$, while the contents of higher sugars increased markedly with an increase in hydrolysis temperature, reaching its highest level $(59.0 \%)$ at $90^{\circ} \mathrm{C}$.

The increase in temperature above $60^{\circ} \mathrm{C}$ caused an essential decrease in the enzyme activity of the saccharifying enzyme, which resulted in a considerably lower glucose content. The obtained results indicate that it is justified to recommend the single-stage method in the case of glucose hydrolysates, but only at $60^{\circ} \mathrm{C}$.

From the comparison of the content of the most important sugar, glucose, obtained at the optimal temperature of $60^{\circ} \mathrm{C}$ with use of two methods under consideration it becomes clear that the single-stage method leads to a higher content $(98.2 \%)$ of glucose than the two-stage one $(96.3 \%)$.

\section{Influence of method of hydrolysis on residual starch content}

The single-stage hydrolysis leads to a higher content of residual starch (Table 1), which did not convert after hydrolysis, than the two-stage one, in either maltose or glucose hydrolysate production. The starch residue after hydrolysis is approximately 4 times higher in the case of the single-stage hydrolysis than in that of the two-stage hydrolysis. Nevertheless, it does not exceed 3\% for glucose hydrolysate and $6 \%$ for maltose hydrolysate. This means that although the single-stage hydrolysis, as compared with the two-stage one, is characterized by slightly higher losses of the starch used for hydrolysis, it may become very useful in certain technical and economic conditions.

Replacing the classical two-stage enzymatic hydrolysis of starch with simultaneous action of liquefying and saccharifying enzymes brings the following advantages: a slightly decrease in energy consumption used for liquefaction process, a more exhausting use of the action of the liquefying enzyme, a decrease in the apparatus cost and a simplification of the technological process. Also, they permit to avoid the necessity of changes in $\mathrm{pH}$ related with the different optimal conditions of the enzymes, namely $\mathrm{pH}$ about 6 for the liquefying enzyme, $\mathrm{pH}$ about 4.5 for glucogenic enzyme and $\mathrm{pH}$ about 5.5 for maltogenic enzyme.

The need for simplifying the technological process of enzymatic hydrolysis is confirmed in many investigations.

Liakopoulou-Kyriakides et al. ${ }^{13}$ performed hydrolysis of corn starch in the form of a 5\% suspension with a simultaneous application of alpha-amylase and glucoamylase. Hydrolysis was performed with application of various animal (pig pancreas), bacterial (Bacillus licheniformis, Bacillus spp.) and fungal (mildew) alphaamylases (Aspergillus niger) as well as fungal (mildew) glucoamylases (Aspergillus niger, Rhizopus), applied in various combinations at temperatures of 40,50 and $60^{\circ} \mathrm{C}$.

Table 1. Comparison of residual starch content after $48 \mathrm{hr}$ hydrolysis

\begin{tabular}{|l|c|c|}
\hline \multirow{2}{*}{ Method of hydrolysis } & \multicolumn{2}{|c|}{ Residual starch [\%] } \\
\cline { 2 - 3 } & $\begin{array}{c}\text { Glucose } \\
\text { hydrolysate }\end{array}$ & $\begin{array}{c}\text { Maltose } \\
\text { hydrolysate }\end{array}$ \\
\hline $\begin{array}{l}\text { Two-stage } \\
\text { hydrolysis }\end{array}$ & 0.6 & 1.1 \\
\hline $\begin{array}{l}\text { Single-stage } \\
\text { hydrolysis }\end{array}$ & 2.5 & 5.7 \\
\hline
\end{tabular}



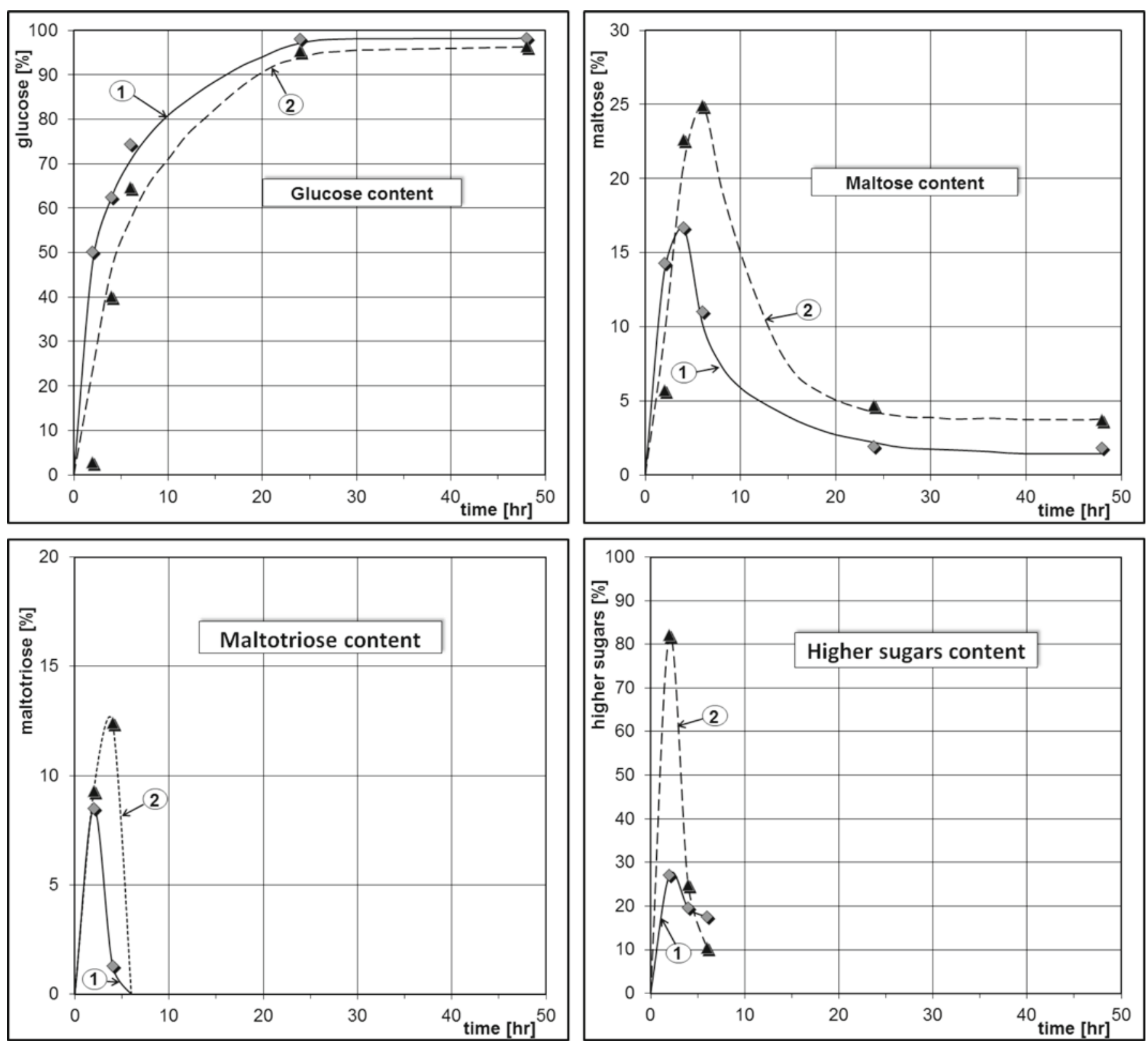

Figure 6. Changes in glucose contents during starch hydrolysis (glucose hydrolysate - during 48 hr hydrolysis)

1. Single-stage method $\left(60^{\circ} \mathrm{C}\right)$

2. Two-stage method (without inactivation of liquefying enzyme)

A simultaneous action of alpha-amylase and glucoamylase on corn starch was also investigated by Fuji and Kawamura ${ }^{14}$, Fuji et al. ${ }^{15}$, Arasaratnam and Balasubramanian ${ }^{16}$, Janse and Pretorius ${ }^{17}$ and Karakatsanis et al. ${ }^{18}$.

Hydrolysis of wheat starch at $90^{\circ} \mathrm{C}$ with a imultaneous action of the commercial thermostable alpha-amylase (Bacillus licheniformis) and the new thermostable alphaglucosidase (Thermococcus hydrothermalis) was performed by Legin et al. ${ }^{7}$. Synergistic action of the liquefying and saccharifying enzymes at the same temperature $\left(90^{\circ} \mathrm{C}\right)$ and $\mathrm{pH}(6.0)$ conditions has shortened the hydrolysis time and reduced the cost related to variations in $\mathrm{pH}$ and temperature accompanying the conventional twostage hydrolysis.

Single-stage enzymatic tapioca starch hydrolysis was performed by Sarbatly ${ }^{8}$. His investigations were aimed, i.a., at limiting the production of a highly viscous solution during the process of starch gelatinising, accompanied by a high energy consumption in the mixing process. Other goals were: diminishing the loss in the activity of enzyme due to high temperature and elimination of heat inter- changers needed to change in the reaction temperature from $105^{\circ} \mathrm{C}$ (liquefaction) to $60^{\circ} \mathrm{C}$ (saccharification). In his work, in the process of starch hydrolysis, commercially available enzymes: alpha-amylase and glucoamylase in the form of a $10 \%$ suspension were used.

A combination of two processes: liquefaction and saccharification, has also been applied to corn hydrolysis with the use of an enzyme representing a combination of the liquefying and the saccharifying ones?.

A single-stage hydrolysis of starch was performed by Janse and Pretorius ${ }^{17}$ with a complex of enzymes obtained from the breeding of Saccharomyces cerevisiae, namely alpha-amylase, glucoamylase and pullulanase.

In particular, the process of one-stage enzymatic hydrolysis of starch can be applied in the energy-saving technology of alcohol production. Such a method of hydrolysis is presented in the patent by Norman et al. ${ }^{19}$. Namely, the classical two-stage hydrolysis of corn starch (crushed corn, 30\% d.s.) in the technology of alcohol production started from the application of liquefaction by bacterial alpha-amylase $\left(85-90^{\circ} \mathrm{C}\right)$ followed 
by warming up to $115-120^{\circ} \mathrm{C}$ and saccharification with the help of glucoamylase at $60^{\circ} \mathrm{C}$. This was compared with one-stage hydrolysis $\left(60^{\circ} \mathrm{C}\right)$ with the application of cyclodextrin glucosyltransferase and glucoamylase. The low-temperature single-stage method for starch hydrolysis was characterised by a $95 \%$ alcohol output, close to that gained in the classical two-stage starch hydrolysis.

In the current work, we dealt with one-stage enzymatic hydrolysis of potato starch in the form of coldsoluble starch. Two combinations of enzymes were in use: the first combination consisted of alpha-amylase (Liquozyme ${ }^{\circledR}$ Supra) and maltogenic alpha-amylase (Maltogenase 4000L), the second one was composed of alpha-amylase (Liquozyme ${ }^{\circledR}$ Supra) and glucoamylase (San Super 360L). Hydrolysis of soluble starch was run in conditions close to those used in the industrial technology of producing starch hydrolysates, namely the substrate concentration of $30 \%$ d.s. of starch (in industrial conditions $-30-40 \%$ d.s. of starch) and the reaction time of $48 \mathrm{hr}$ (in industrial conditions - 48-72 hr). For the former combination of enzymes the optimum working temperature amounted to $80^{\circ} \mathrm{C}$ and for the latter one $-60^{\circ} \mathrm{C}$. The check of the content of hydrocarbons revealed that glucose represented the main product of hydrolysis performed with the application of the first combination of enzymes. Its content was close to that obtained during the two-stage hydrolysis (97\%). Maltose was the main product of hydrolysis performed with the use of the second combination of enzymes and, again, its content was close to that obtained in classical twostage hydrolysis $(52 \%)$.

It follows from the investigation that during the single-stage enzymatic hydrolysis relying upon simultaneous action of liquefying and saccharifying enzymes a synergistic and complementary action of either enzyme is observed. In the initial phase of hydrolysis, alpha-amylase produces saccharides with a lower molecular mass representing the substrate for the action of the saccharifying enzyme - glucoamylase or maltogenic amylase. The action of glucoamylase which also enables the cleaving of chemical bonds at branch points, leads to a production of successive saccharides with lower and lower molecular masses. They represent a new convenient substrate for the action of alpha-amylase ${ }^{14,15}$. Application of singlestage hydrolysis of starch enhances the hydrolysis yield by a more exhaustive use of the activity of enzymes, 2 . Synergism between simultaneous action of liquefying and saccharifying enzyme during starch conversion elicits considerable interest ${ }^{21}$.

\section{CONCLUSIONS}

The unconventional single-stage method for starch hydrolysis leads to results comparable to those obtained with the two-stage method. Thus, it is advisable to conduct further research in order to optimize the conditions of the single stage-method.

In the production of maltose hydrolysates, the single-stage method yields the most desirable results at $80^{\circ} \mathrm{C}$.

In the production of glucose hydrolysates, the single-stage method yields the most desirable results at $60^{\circ} \mathrm{C}$.

The possibility to choose the method of starch hydrolysis (the single-stage or two-stage method) gives the technologist a better opportunity to modify the quality of starch hydrolysates (DE, carbohydrate composition) and the degree of processing reduction (constant temperature, simultaneous dosage of enzymes).

\section{ACKNOWLEDGMENTS}

Special thanks are due to Chemet Co. (Poland) for the delivery of Solamyl.

\section{LITERATURE CITED}

1. Radley, J.A. (1982). Starch production technology. Applied Science Publishers, London. England.

2. Reilly, P.J. (1985). Enzymatic degradation of starch.. In G.M.A. Beynum \& J.A. Roels (Eds.), Starch conversion technology, pp. 101-142. New York: Marcel Dekker.

3. Alexander, R.J. \& Zobel, H.F. (1994). Developments in carbohydrate chemistry. The American Association of Cereal Chemistry, St. Paul, Minnesota.

4. Guzman-Maldonado, H. \& Parades-Lopez, O. (1995). Amylolytic enzymes and products derived from starch: a review. Crit. Rev. Food Sci. Nutr. 35 (5). 373-403. DOI: 10.1080/10408399509527706.

5. Bryjak, J. (1999). Enzymatic starch hydrolysis to maltodextrin and starch syrups. Biotechnologia. 1, 80-199 (in Polish).

6. Schenck, F.W. (2002). Starch hydrolysates: an overview. Int. Sugar J. 1238 (104) 82-89.

7. Legin, E, Copinet, A. \& Duchiron, F. (1998). A single step high temperature hydrolysis of wheat starch. Starch/Stärke 50 (2-3), 84-89. DOI: 10.1002/(SICI)1521379X(199803)50:2/3<84::AID-STAR84>3.0.CO;2-4.

8. Sarbatly, R. (2007). The simultaneous enzymatic hydrolysis of tapioca starch for instant formation of glucose. J. Applied Sci. 7 (15), 2057-2062. DOI: 10.3923/jas.2007.2057.2062.

9. Wang, P., Singh, V., Xue, H. \& Johnston, D.B. (2007). Comparison of raw starch hydrolyzing enzyme with conventional liquefaction and saccharification enzymes in dry-grind corn processing. Cereal Chem. 84 (1), 10-14. DOI: 10.1094/ CCHEM-84-1-0010.

10. Whistler, R.L., BeMiller, J.N. \& Paschall, E.F. (1984). Starch: Chemistry and Technology. Academic Press, Inc. New York.

11. Rauscher, K. (1956). Untersuchung von Lebensmitteln. Fachbuchverlag, Leipzig, Germany.

12. Zielonka, R., Jarosławski, L. \& Słomińska, L. (2010). Elaboration and comparison of methods for efficient determination of starch hydrolysis. Zesz. Probl. Post. Nauk Rol.. 557, 423-433 (in Polish).

13. Liakopoulou-Kyriakides, M., Karakatsanis, A., Stamatoudis, M. \& Psomas, S. (2001). Synergistic hydrolysis of crude corn starch by $\alpha$-amylases and glucoamylases of various origins. Cereal Chem. 78 (5), 603-607. DOI: 10.1094/CCHEM 2001785.603.

14. Fujii, M. \& Kawamura, Y. (1985). Synergistic action of $\alpha$-amylase and glucoamylase on hydrolysis of starch. Biotechnol. Bioeng. 27 (3), 260-265. DOI: 10.1002/bit.260270308.

15. Fujii, M., Homma, T. \& Taniguchi, M. (1988). Synergism of $\alpha$-amylase and glucoamylase on hydrolysis of starch granules. Biotechnol. Bioeng. 32, 910-915. DOI: 10.1002/bit.260320710.

16. Arasaratnam, V. \& Balasubramanian, K. (1993). Synergistic action of $\alpha$-amylase and glucoamylase on raw corn. Starch/Stärke. 45 (6), 231-233. DOI: 10.1002/star.19970490505.

17. Janse, B.J.H. \& Pretorius, I.S. (1995). One-step enzymatic hydrolysis of starch using a recombinant strain of Saccharomyces cerevisiae producing $\alpha$-amylase, glucoamylase and pullulanase. App. Microbiol. Biotechnol. 42 (6), 878-883. DOI: 10.1007/BF00191185.

18. Karakatsanis, A., Liakopoulou-Kyrakides, M. \& Stamatoudis, M. (1997). Hydrolysis of various starches by synergistic 
action of $\alpha$-amylase and glucoamylase in aqueous two phase impeller agitated systems. Starch/Stărke. 49, 194-199. DOI: 10.1002/star.19970490505.

19. Norman, B.E.L., Vikso-Nielsen, A., Olsen, H.S. \& Petersen, S. (2009). U.S. Patent No. 2,009,0142817 Washington, D.C.: US Patent and Trademark Office.

20. Franco, J.M., Murado, M.A., Siso, M.I.G., Miron, J. \& Gonzalez, M.P. (1989). A HPLC method for specific determination of $\alpha$-amylase and glucoamylase in complex enzymatic preparations. Chromatographia. 27, 328-332. DOI: 10.1007/ BF02321279.

21. Tomasik, P. \& Horton, D. (2012). Enzymatic conversion of starch. In D. Horton, Advances in Carbohydrate Chemistry and Biochemistry, pp. 59-436. Oxford: Academic Press. DOI: 10.1016/B978-0-12-396523-3.00001-4. 